\title{
Diaspora Literature and Stereotypes Concerning Contemporary Art in Africa
}

Author: Jacob Shai

\begin{abstract}
One positive facet of globalization is the fusion of creative elements from various cultures of the world. The essence of this global shift has drastically changed the contemporary African art market, rendering post modern representations of this great continent, its people and creatures in new and enlightening contexts. Modern African artists work to explore new concepts by interpreting them within their indigenous traditions or by reflecting their authentic African situation or experience in their art work. However, maybe it is less the content or style of the works than the origin, location or structure of the artist that exhibit them. If you talk about the contemporary art world today you are really referring to a world of art. Modern art cites from Sao Paolo to London, from Kassel to Cape Town all embrace an array of artists and cultures from the four corners of the globe, many of whom were born in Africa. Who are these global artists? And when they make art, do they make African Art? Or do they make modern African art? Contemporary Art from Africa or Postmodern African Art? Are these descriptions only applicable for artists that are from Africa? Or who live in Africa?
\end{abstract}

Keyword: Diaspora Literature; Stereotypes; Postmodern; Culture; Africa;

\section{Introduction}

Diaspora Literature involves an idea of a homeland, a place from where the displacement occurs and narratives of harsh journeys undertaken on account of economic compulsions. Basically Diaspora is a minority community living in exile. The Oxford English Dictionary 1989 Edition (second) traces the etymology of the word 'Diaspora' back to its Greek root and to its appearance in the Old Testament (Deut: 28:25) as such it references. God's intentions for the people of Israel to be dispersed across the world. The Oxford English Dictionary here commences with the Judic History, mentioning only two types of dispersal: The "Jews living dispersed among the gentiles after the captivity" and The Jewish Christians residing outside the Palestine.

34 | Diaspora Literature and Stereotypes Concerning Contemporary Art in Africa 
The dispersal (initially) signifies the location of a fluid human autonomous space involving a complex set of negotiation and exchange between the nostalgia and desire for the Homeland and the making of a new home, adapting to the power, relationships between the minority and majority, being spokes persons for minority rights and their people back home and significantly transacting the Contact Zone - a space changed with the possibility of multiple challenges.

- People migrating to another country in exile home

- Living peacefully immaterially but losing home

- Birth of Diaspora Literature

However, the 1993 Edition of Shorter Oxford's definition of Diaspora can be found. While still insisting on capitalization of the first letter, 'Diaspora' now also refers to 'anybody of people living outside their traditional homeland.

In the tradition of indo-Christian the fall of Satan from the heaven and humankind's separation from the Garden of Eden, metaphorically the separation from God constitute diasporic situations. Etymologically, 'Diaspora' with its connotative political weight is drawn from Greek meaning to disperse and signifies a voluntary or forcible movement of the people from the homeland into new regions." (Pp.68-69)

Under Colonialism, 'Diaspora' is a multifarious movement which involves:

- The temporary of permanent movement of Europeans all over the world, leading to Colonial settlement. Consequen's, consequently the ensuing economic exploitation of the settled areas necessitated large amount of labor that could not be fulfilled by local populace. This leads to:

- The Diaspora resulting from the enslavement of Africans and their relocation to places like the British colonies. After slavery was out lawed the continued demand for workers created indenturement labor. This produces:

- Large bodies of the people from poor areas of India, China and other to the West Indies, Malaya Fiji. Eastern and Southern Africa, etc. (see-http://www.postcolonialweb.com)

William Sarfan points out that the term Diaspora can be applied to expatriate minority communities whose members share some of the common characteristics given hereunder: 
1. They or their ancestor have been dispersed from a special original 'centre' or two or more 'peripheral' of foreign regions;

2. They retain a collective memory, vision or myth about their original homeland-its physical location, history and achievements;

3. They believe they are not- and perhaps cannot be- fully accepted by their lost society and therefore feel partly alienated and insulted from it;

4. They regard their ancestral homeland as their, true, ideal home and as the place to which they or their descendents would (or should) eventually return- when conditions are appropriate;

5. They believe they should collectively, be committed to the maintenance or restoration of their homeland and its safety and prosperity; and

6. They continue to relate, personally and vicariously, to that homeland in one way or another, and their ethno- communal consciousness and solidarity are importantly defined by the existence of such a relationship ;( Safren Willam cited in Satendra Nandan: 'Diasporic Consciousness' Interrogative Post-Colonial: Column Theory, Text and Context, Editors: Harish Trivedi and Meenakshi Mukherjee; Indian Institute of Advanced Studies 1996, p.53)

There lies a difficulty in coming to terms with diaspora, and as such it introduces conceptual categories to display the variety of meanings the word invokes. Robin Cohen classifies Diaspora as:

1. Victim Diasporas

2. Labour Diasporas

3. Imperial Diasporas

4. Trade Diasporas

5. Homeland Diasporas

6. Cultural Diasporas

\section{Finding and Discussion}

The author finds a common element in all forms of Diaspora; these are people who live outside their 'natal (or imagined natal) territories' (ix) and recognize that their traditional homelands are reflected deeply in the languages they speak, religion they adopt, and cultures they produce. Each of the categories of Diasporas underline a particular cause of migration usually associated with particular groups of people. So for example, the Africans through their 
experience of slavery have been noted to be victims of extremely aggressive transmigrational policies. (Cohen)

Though in the age of technological advancement which has made the traveling easier and the distance shorter so the term Diaspora has lost its original connotation, yet simultaneously it has also emerged in another form healthier than the former. At first, it is concerned with human beings attached to the homelands. Their sense of yearning for the homeland, a curious attachment to its traditions, religions and languages give birth to diasporic literature which is primarily concerned with the individual's or community's attachment to the homeland. The migrant arrives 'unstuck from more than land' (Rushdie). he runs from pillar to post crossing the boundries of time, memory and History carrying 'bundles and boxes' always with them with the vision and dreams of returning homeland as and when likes and finds fit to return. Although, it is an axiomatic truth that his dreams are futile and it wouldn't be possible to return to the homeland is 'metaphorical' (Hall).

The longing for the homeland is countered by the desire to belong to the new home, so the migrant remains a creature of the edge, 'the peripheral man' (Rushdie). According to Naipaul the Indians are well aware that their journey to Trinidad 'had been final' (Andse Dentseh,) but these tensions and throes remain a recurring theme in the Diasporic Literature.

\section{Diaspora}

- Forced

- Voluntary

Indian Diaspora can be classified into two kinds:

1. Forced Migration to Africa, Fiji or the Caribbean on account of slavery or indentured labour in the 18th or 19th century.

2. Voluntary Migration to U.S.A., U.K., Germany, France or other European countries for the sake of professional or academic purposes.

According to Amitava Ghose-'the Indian Diaspora is one of the most important demographic dislocation of Modern Times'(Ghosh,) and each day is growing and assuming the form of representative of a significant force in global culture. If we take the Markand Paranjpe, we will find two distinct phases of Diaspora, these are called the visitor Diaspora and Settler Diaspora much similar to Maxwell's 'Invader' and 'Settler' Colonialist.

37 | Diaspora Literature and Stereotypes Concerning Contemporary Art in Africa 
The first Diaspora consisted of dispriveledged and subaltern classes forced alienation was a one way ticket to a distant diasporic settlement. As, in the days of yore, the return to Homeland was next to impossible due to lack of proper means of transportation, economic deficiency, and vast distances so the physical distance became a psychological alienation, and the homeland became the sacred icon in the diasporic imagination of the authors also.

But the second Diaspora was the result of man's choice and inclination towards the material gains, professional and business interests. It is particularly the representation of privilege and access to contemporary advanced technology and communication. Here, no dearth of money or means is visible rather economic and life style advantages are facilitated by the multiple visas and frequent flyer utilities. Therefore, Vijay Mishra is correct when he finds $\mathrm{V}$ S Naipaul as the founding father of old diaspora but it is also not wrong to see Salman Rushdie as the representative of Modern (second) Diaspora V S Naipaul remarkably portrays the search for the roots in his 'A House for Mr. Biswas:

\footnotetext{
"to have lived without even attempting to lay claim to one's portion of the earth; to have lived and died as one has been born, unnecessary and accommodated.(Naipaul,14) similarly Mohan Biswas's peregrination over the next 35 years, he was to be a wanderer with no place to call his own'(ibid. 40)
}

In the same manner, Rushdie's Midnight Children and Shame are the novels of leave taking... from the country of his birth (India) and from that second country (Pakistan) where he tried, half-heartedly to settle and couldn't." (Aizaz Ahmad, 135)

Here the critique of Paranjape generates the debate of competing forms of writing: Diaspora or domiciled those who stayed back home and importantly a competitive space for the right to construct the homeland, so he points out the possibility of harm by 'usurping the space which native self- representations are striving to find in the International Literary Market place and that they may 'contribute to the Colonization of the Indian psyche by pondering to Western tastes which prefer to see India in a negative light.' The works of various authors like Kuketu Mehta, Amitava Ghosh, Tabish, Khair, Agha Shahid Ali, Sonali Bose, Salman Rushdie confirm a hybridity between diasporic and domiciled consciousness. They are National, not Nationalistic inclusive not parochial, respecting the local while being ecumenical, celebrating human values and Indian pluralism as a vital 'worldliness'. (Ashcraft, 31-56) 
The diasporian authors engage in cultural transmission that is equitably exchanged in the manner of translating a map of reality for multiple readerships. Besides, they are equipped with bundles of memories and articulate an amalgam of global and national strands that embody real and imagined experience. Suketu Mehta is advocate of idea of home is not a consumable entity. He says: You cannot go home by eating certain foods, by replaying its films on your T.V. screens. At some point you have to live there again."(Mehta, 13)

So his novel Maximum City is the delineation of real lives, habits, cares, customs, traditions, dreams and gloominess of Metro life on the edge, in an act of morphing Mumbai through the unmaking of Bombay. It is also true, therefore, that diasporic writing is full of feelings of alienation, loving for homeland dispersed and dejection, a double identification with original homeland and adopted country, crisis of identity, mythnic memory and the protest against discrimination is the adopted country. An Autonomous space becomes permanent which non- Diasporas fail to fill. M K Gandhi, the first one to realize the value of syncretic solutions' hence he never asked for a pure homeland for Indians in South Socio-cultural space and so Sudhir Kumar confirms Gandhi as the first practitioner of diasporic hybridity. Gandhi considered all discriminations of high and low, small or great, Hindu or Muslim or Christian or Sikh but found them 'All were alike the children of Mother India.'

Diasporic writings are to some extent about the business of finding new Angles to enter reality; the distance, geographical and cultural enables new structures of feeling. The hybridity is subversive. It resists cultural authoritarianism and challenges official truths."(Ahmad Aizaz, In Theory: Classes, Nations, Literatures; OUP, 1992,p.126) one of the most relevant aspect of diasporic writing is that it forces, interrogates and challenges the authoritative voices of time (History). The Shadow Line of Amitav Ghosh has the impulse when the Indian States were complicit in the programmes after Indira Gandhi's assassination. The author elaborates the truth in the book when he says:

\footnotetext{
"In India there is a drill associated with civil disturbances, a curfew is declared, paramilitary units are deployed; in extreme cares, the army monarchs to the stricken areas. No city in India is better equipped to perform this drill than New Delhi, with its high security apparatus."(Amitava Ghosh, 51)
}

The writers of Diaspora are the global paradigm shift, since the challenges of Postmodernism to overreaching narratives of power relations to silence the voices of the 
dispossessed; these marginal voices have gained ascendance and even found a current status of privilege. These shifts suggest:

"That it is from those who have suffered the sentence of history-subjugation, domination, Diaspora, displacement- that we learn our most enduring lessons for living and thinking."(Bhabha, 172)

The novels of Amitav Ghosh especially the hungry tide in which the character Kanai Dutt is cast together "with chance circumstance with a Cetologist from the US, Priya Roy studying fresh water Dalphines, The Oracaella Brebirostris. The multiple histories of the Sunderbans became alive when the diaries of Marxist school teacher Nirmal came to light. He withdraws from the romance of political activism and came to settle with his wife Nilima in Lucibari and the relation between them is exemplified in the pragmatism of Nilima:

\footnotetext{
"You live in a dream world- a haze of poetry Such passages of the novel points towards the metaphorical distinctions between the centre and margins, made narrative and little histories the well knows gods and the gods of small things. In the novels of Ghosh an assault of unarmed settlers Morich Jhapi, in order to evict them forcively is carried out by gangsters hired by states. They had been "assembling around the island... they burnt the settlers, hearts, they sank their boats, they lay waste their fields."(ibid)
}

Similarly there are a number of novels by South Asian and British Writers on the theme of partition a blatant reality in the global history. Partition was the most traumatic experience of division of hearts and communities. Similarly, Ice Candy Man comprises 32 chapters and provides a peep into the cataclysmic events in turmoil on the sub continent during partition, the spread of communal riots between the Hindu and Sikhs on the one side and the Muslim on the other. The Muslims were attached at a village Pirpindo and the Hindus were massacred at Lahore. It was partition only that became the cause of the biggest bloodshed and brutal holocaust in annals of mankind. Lenny on eight years child narrates the chain of events on the basis of her memory. How she learns from her elders and how she beholds the picture of divided India by her own eyes in the warp and woof of the novel.

Most of the major novels of South Asia are replete with the diasporic consciousness which is nothing but the witness of the all the happenings of social realities, longings and 
feeling of belonging. Train To Pakistan, The Dark Dancer, Azadi, Ice Candy Man, A Bend In The Ganges, Twice Born, Midnight's Children, Sunlight on A Broken Column, Twice Dead, The Rope and Ashes and Petals all these novels abound in the same tragic tale of woe and strife from different angles. Most of the fictions of South Asian Countries are written in the background of post- colonial times and the same South Asian countries were under the colonial rules of the English. After a long battle of independence when those countries were liberated, other bolt from the blue of partition happened. This theme became whys and wherefores of the most of South Asian novels and the popularity of it will prognosticate its golden future.

\section{Postmodern African Artists Endure a Mixed Blessing}

Defining the contemporary artists' identity based on cultural or geographical boundaries has always been applied, especially in the African case. Unfortunately for many postmodern African artists this is a mixed blessing. Possessing African roots can be seen as a source of pride, an irrelevant fact, or a perpetual curse.

Western stereotypes are steadfast and hard to eliminate. Western cultural presuppositions have negatively affected the presentation and interpretation of contemporary African art. In the Washington Post the Tanzanian artist Kiure Msangi quoted the reaction of a journalist: "Do you use acrylic paint? But that is not African!" Kiure Msangi proceeded: "If I would have used in some canvases acrylic paint with cow dung, I am sure the critics would have loved it".

\section{Can the World's Contemporary Art Culture Benefit from the African Experience?}

Although the stereotypes still exist, there is a growing upward trend in the sale and exhibition of contemporary "African Art". Both collectors and the general public are investing in exciting vibrant paintings, sculptures, installations and digital art. These contemporary art collections bring delight and financial reward, while enriching many homes with modern form and color.

The 21st century has been with us for some time and "African Art" is beginning to solidify the respect it has gained in recent years. This contemporary art should not be discarded as a strange sub-category, but be recognized for its sophistication and quality. These modern works of art are being produced by a professional and ethnically diverse art community that spans the globe.

41 | Diaspora Literature and Stereotypes Concerning Contemporary Art in Africa 


\section{References}

Aijaz, A. (1992). In theory: Nations, classes, literatures. Radical Thinkers, 25.

Bhabha, H. K. (2012). The location of culture. routledge.

Chrisman, L., \& Williams, P. (2015). Colonial discourse and post-colonial theory: A reader. Routledge.

Cohen, R. (2002). Global diasporas: An introduction. Routledge.

Darkwa, S. K. (2018). From Brain-Drain to Brain-Gain: The African-Diaspora Community and Development in Africa. Journal of Pan African Studies, 12(5), 14-36.

Dickinson, J. (2015). Articulating an Indian diaspora in South Africa: The Consulate General of India, diaspora associations and practices of collaboration. Geoforum, 61, 79-89.

Farred, G. (2019). Midfielder's Moment: coloured literature and culture in contemporary South Africa. Routledge.

Feldner, M. (2019). Contexts: New African Diaspora, Nigerian Literature, and the Global Literary Market. In Narrating the New African Diaspora (pp. 13-36). Palgrave Macmillan, Cham.

Ghosh, A. (1989). The diaspora in Indian culture. Public Culture, 2(1), 73-78.

Ghosh, A. (1995). The Ghosts of Mrs Gandhi. the Imam and the Indian: Prose pieces, 46-62.

Habibi, H. (2018). PROTECTING NATIONAL IDENTITY BASED ON THE VALUE OF NATION LOCAL WISDOM. International Journal of Malay-Nusantara Studies, 1(2), 24-40.

Mishra, V. (2007). The literature of the Indian diaspora: theorizing the diasporic imaginary. Routledge.

Nelson, S. (2017). "Daringly Experimental and Versatile": African Arts and the Contemporary. african arts, 50(1), 16-21.

Pather, J., \& Boulle, C. (Eds.). (2019). Acts of Transgression: Contemporary Live Art in South Africa. Wits University Press.

Perez-Martin, F., \& Freedman, K. (2019). Social Justice in Art Education: An Example from Africa's Last Colony. The International Encyclopedia of Art and Design Education, 1-12.

Sadler, M. E. (2018). Arts of West Africa:(excluding Music). Routledge.

Walsh, R. (2003). Global Diasporas.

Willis, D., Toscano, E., \& Nelson, K. B. (Eds.). (2019). Women and Migration: Responses in Art and History. Open Book Publishers.

42 | Diaspora Literature and Stereotypes Concerning Contemporary Art in Africa 